УДК: 615.072

DOI 10.25230/conf11-2021-32-35

\title{
СОДЕРЖАНИЕ ТЯЖЕЛЫХ МЕТАЛЛОВ В ЖИРНЫХ МАСЛАХ И МАСЛЯНЫХ ЭКСТРАКТАХ
}

Галенко М. С.

ФГАОУ ВПО Первый МГМУ им. И. М. Сеченова marta.galenko@mail.ru

В связи с тенденцией к увеличению индустриальных выбросов в окружающую среду и загрязнением флоры и фауны различными экотоксикантами, были изучены образцы растительных масел по содержанию тяжелых металлов ( $\mathrm{Pb}, \mathrm{Cd}, \mathrm{Cu}, \mathrm{Fe})$ методом ААC. Установлено, что содержание определяемых элементов находилось в диапазоне от 0,037-1,474 мг/кг, так же обнаружено что в 20 \% образцов содержание свинца было ниже предела 
обнаружения метода. Исходя из полученных данных рассчитано возможное поступление тяжелых металлов в организм человека с этими маслами и проведена оценка безопасности их использования.

Ключевые слова: масла жирные, тяжелые металлы.

Введение. В настоящее время жирные масла широко применяются в качестве лекарственных средств и вспомогательных веществ. Оценку безопасности их использования проводят в соответствии с требованиями ГФ XIV издания ОФС.1.5.2.0002.15 «Масла жирные растительные» и ОФС.1.5.3.0009.15 «Определение содержания тяжелых металлов и мышьяка в лекарственном растительном сырье и лекарственных растительных препаратах» [1].

Источником получения жирных масел является растительное сырьё, которое получают от растений, собранных в различных регионах. Экологическая обстановка окружающей среды во многих районах характеризуется наличием различных экотоксикантов (тяжелых металлов, пестицидов, радионуклидов и др.). В результате этого, лекарственные растения в местах их произрастания могут накапливать тяжелые металлы (ТМ), пестициды и другие токсиканты. Поэтому практический интерес представляет сравнительное изучение содержания тяжелых металлов в жирных маслах различных наименований.

Цель работы - определить содержание тяжелых металлов в жирных маслах медицинского применения и оценить их возможное поступление в организм человека.

Материалы и методы. Объектами исследования были образцы касторового, персикового, оливкового и подсолнечного масел и облепиховое масло, реализуемых через аптечную сеть. Пробоподготовку образцов к анализу проводили по методике ГОСТ методом кислотной экстракции (ТМ извлекали из масла соляной кислотой (1:1); разделяли водный и масляный слои в делительной воронке; выпаривали полученный экстракт в тигле и обугливали его на плитке, далее сжигали в муфельной печи при температуре $450{ }^{\circ} \mathrm{C}$ до серой золы, которую растворяли в азотной кислоте $1: 1$, выпаривали раствор до влажных солей, с последующим их растворением в азотной кислоте $1 \%$ и доведением до объема 25 мл в мерной колбе) [2]. Далее определяли содержания свинца, кадмия, меди и железа методом атомноабсорбционной спектроскопии на приборе Analityk jena «ContrAA 300», Германия.

Результаты и обсуждение. Исследование показало, что среднее содержание ТМ в маслах составляло 0,037-1,474 мг/кг, что не превышало допустимого содержания по ОФС.1.5.3.0009.15 (нормы ГФ XIV $\mathrm{Pb} 6.0$ мг/кг; $\mathrm{Cd} 1.0$ ) и убывало в ряду: $\mathrm{Fe} \rightarrow \mathrm{Cu} \rightarrow \mathrm{Cd} \rightarrow \mathrm{Pb}$ $(1,185 \rightarrow 0,09 \rightarrow 0,05 \rightarrow 0,008$ мг/кг). Содержание $\mathrm{Pb}$ в $20 \%$ исследованных образцов было ниже предела обнаружения метода $(0,001$ мг/кг) (табл. 1$)$.

Таблица 1. Среднее содержание ТМ в жирных маслах, \%

\begin{tabular}{|c|c|c|c|c|}
\hline Наименование масла & $\mathrm{Pb}$ & $\mathrm{Cd}$ & $\mathrm{Cu}$ & $\mathrm{Fe}$ \\
\hline Оливковое & $0,005 \pm$ & $0,056 \pm$ & $0,039 \pm$ & $0,079 \pm$ \\
\hline Касторовое & $0,008 \pm$ & $0,056 \pm$ & $0,29 \pm$ & $1,263 \pm$ \\
\hline Персиковое & $<п .0$. & $0,053 \pm$ & $0,27 \pm$ & $1,302 \pm$ \\
\hline Подсолнечное & $0,006 \pm$ & $0,037 \pm$ & $0,135 \pm$ & $0,64 \pm$ \\
\hline Облепиховое & $0,012 \pm$ & $0,052 \pm$ & $0,039 \pm$ & $1,474 \pm$ \\
\hline
\end{tabular}

Касторовое масло применяется в качестве слабительного средства в дозировке 15-30 г 1 раз в день для взрослого человека [3]. Облепиховое масло используется при повреждении кожи и слизистых оболочек в качестве наружного средства, при язвенной болезни желудка и двенадцатиперстной кишки принимается внутрь по 5 г 2-3 раза в день. [4]. Была проведена оценка возможного поступления тяжелых металлов при использовании масел в качестве 
лекарственных средств перорально. Было выявлено, что с точки зрения содержания тяжелых металлов исследованные образцы соответствуют требованиям нормативной документации и являются безопасными для их употребления (табл. 2).

Таблица 2. Оценка поступления ТМ в организм человека при использовании жирных масел в качестве лекарственных средств [5; 6]

\begin{tabular}{|l|c|c|c|c|}
\hline \multicolumn{1}{|c|}{ Масло } & $\begin{array}{c}\text { Суточная } \\
\text { доза, } \Gamma\end{array}$ & $\begin{array}{c}\text { Возможное } \\
\text { поступление, мг }\end{array}$ & $\begin{array}{c}\text { Уровни допустимого } \\
\text { ежедневного } \\
\text { поступления, мг }\end{array}$ & $\begin{array}{c}\text { Адекватные } \\
\text { уровни } \\
\text { потребления, мг }\end{array}$ \\
\hline Касторовое & $15-30$ & $\mathrm{~Pb}-0,0001-0,0002$ & $\mathrm{~Pb}-10$ & $\mathrm{Cu}-1$ \\
& & $\mathrm{Cd}-0,0008-0,0017$ & $\mathrm{Cd}-5$ & 15 (для \\
& & $\mathrm{Cu}-0,0044-0,0087$ & $\mathrm{Cu}-5$ & 10 (для женщин) \\
& & $\mathrm{Fe}-0,0189-0,0379$ & $\mathrm{Fe}-45$ & \\
\hline
\end{tabular}

При анализе литературных данных было найдено, что содержание тяжелых металлов варьируется в диапазоне от 0,004 до 5,78 мг/кг, что соотносится с полученными нами данными [7-9].

Заключение. Установлено, что наиболее экологически чистым по содержанию свинца является оливковое масло, кадмия - подсолнечное, меди - оливковое и облепиховое, железа оливковое. Это необходимо учитывать при выборе вспомогательных веществ при производстве препаратов и масляных экстрактов, а также для оценки безопасности использования масел в качестве лекарственных средств.

Благодарность. Работа проводилась под руководством доктора фармацевтических наук, профессора Гравель Ирины Валерьевны.

\section{Литература}

1. Государственная фармакопея Российской Федерации XIV. - М.: Издательство «Научный центр экспертизы средств медицинского применения», 2015. - Т. II.

2. Гравель И.В., Галенко М.С. Пробоподготовка при определении содержания тяжелых металлов в жирных маслах // Химико-фармацевтический журнал. - 2020. - №12. - 56-59.

3. Регистр лекарственных средств России. Касторовое масло (Ricini oleum) [Электронный ресурс]. - Режим доступа: https://www.rlsnet.ru/pcr_tn_id_1688.htm

4. Регистр лекарственных средств России. Облепиховое масло (Hippophae oleum) [Электронный ресурс]. - Режим доступа: https://www.rlsnet.ru/tn_index_id_7320.htm

5. European Pharmacopoeia, $8^{\text {th }}$ edition. -2014.

6. Методические рекомендации. Рекомендуемые уровни потребления пищевых и биологически активных веществ (МР 2.3.1.1915-04). - М.: Издательство стандартов, 2004.

7. Leila Farzin, M. E. Moassesi Determination of metal contents in edible vegetable oils produced in iran using microwave-assisted acid digestion // Quarterly Journal of Applied Chemical Research. -2014.

8. Ashraf, M.W., Khobar Al. Levels of selected heavy metals in varieties of vegetable oils consumed in kingdom of saudi arabia and health risk assessment of local population // Journal of the Chemical Society of Pakistan. - Vol. 36(4). - P. 691-698.

9. Karima Bakkali, Natividad Ramos Martos, Badredine Souhail, Evaristo Ballesteros Determination of heavy metal content in vegetables and oils from spain and morocco by inductively coupled plasma mass spectrometry // Analytical Letters. - 2012. - Vol. 45. - Is. 8. 


\section{THE CONTENT OF HEAVY METALS IN FATTY OILS AND OIL EXTRACTS}

\section{Galenko M.S.}

Due to the tendency to an increase in industrial emissions into the environment and pollution of flora and fauna with various ecotoxicants, we studied the samples of vegetable oils for the content of heavy metals $(\mathrm{Pb}, \mathrm{Cd}, \mathrm{Cu}, \mathrm{Fe})$ by the method of atomic absorption spectroscopy (AAS). We established that the content of the determined elements was in the range from $0.037-1.474 \mathrm{mg} / \mathrm{kg}$, we also found that in $20 \%$ of the samples the lead content was below the method's detection limit. Based on the obtained data, we calculated the possible intake of heavy metals into the human body with these oils and we evaluated the safety of their use.

Key words: fatty oils, heavy metals. 